\title{
Penyelesaian kecelakaan lalu lintas pelaku anak
}

\section{Completion of accident traffic with children perpetrator}

\author{
Kumala Enggar Anjarani \\ Program Studi Magister Studi Kepolisian, Sekolah Pascasarjana, Universitas Airlangga \\ Surabaya, 60286, Jawa Timur, Indonesia \\ E-mail: kumala.enggar.anjarani-2015@pasca.unair.ac.id
}

\begin{abstract}
Abstrak
Tujuan dari penelitian ini adalah untuk menganalisis strategi untuk menyelesaikan kecelakaan lalu lintas dari pelaku anak dengan pengalih perhatian di Mojokerto. Metode penelitian yang digunakan adalah pendekatan metode kualitatif. Hasil penelitian ini menunjukkan bahwa deskripsi kecelakaan lalu lintas adalah yang paling dominan disebabkan oleh anak-anak dan remaja, yang kemudian mengusulkan metode atau pendekatan pengalihan. Kendala dalam melaksanakan penyelesaian lalu lintas pelaku anak adalah pemahaman masyarakat tentang pengalihan, pemikiran antara korban dan pihak-pihak yang berkonflik dengan hukum untuk mencapai kesepakatan dan pemahaman yang berbeda dalam menangani anak-anak yang berkonflik dengan hukum di antara petugas penegak hukum. Strategi mengatasi kecelakaan lalu lintas anak dengan pendekatan pengalihan di Mojokerto adalah mengadakan sosialisasi tentang pengalihan di antara masyarakat, upaya untuk menyatukan pemikiran antara korban dan anak-anak yang berkonflik dengan hukum untuk mencapai kesepakatan dan membangun komunikasi intensif dengan petugas penegak hukum lainnya.
\end{abstract}

Kata kunci: pengalihan; kecelakaan; lalu lintas; anak-anak; sosialisasi

\begin{abstract}
Diversion is a basic idea to eliminate the negative effects of the criminal justice system on children. The purpose of this study was to analyze the strategy for resolving traffic accidents of child perpetrators with a diversionary in Mojokerto. The research method used is a qualitative method approach. The results of this study indicate that the description of traffic accidents are the most dominant caused by children and adolescents, which is then proposed a diversion method or approach. Constraints in carrying out the settlement of child perpetrators traffic are the people's understanding of diversion, the thought between the victims and the parties in conflict with the law in order to achieve different agreements and understandings in handling children in conflict with the law among law enforcement officers. The strategy of resolving child traffic accidents with a diversionary approach in Mojokerto is to hold socialization about diversion among the community, an effort to unite the thoughts between the victims and the children in conflict with the law in order to reach an agreement and establish intensive communication with other law enforcement officers.
\end{abstract}

Keywords: diversion; accident; traffic; children; socialization

\section{Pendahuluan}

Kabupaten Mojokerto adalah sebuah kabupaten di Provinsi Jawa Timur yang secara resmi didirikan pada tanggal 9 Mei 1293 merupakan wilayah tertua ke-10 di Provinsi Jawa Timur. Kabupaten ini berbatasan dengan Kabupaten Lamongan di utara, Kabupaten Gresik, Kabupaten Sidoarjo, dan Kabupaten Pasuruan di timur, Kabupaten Malang dan Kota Batu di selatan, serta Kabupaten Jombang di barat. Kabupaten Mojokerto terdiri atas 18 kecamatan, yang dibagi lagi atas sejumlah desa dan kelurahan. Jumlah pendudukan di Kabupaten Mojokerto 1.118.358 orang. Sayangnya, jumlah penduduk yang relatif tinggi tersebut juga diimbangi dengan angka kecelakaan yang relatif tinggi pula. Di samping itu, angka jumlah penduduk yang meningkat mempengaruhi peningkatan angka kecelakaan lalu lintas selama 2015-2017. Angka kecelakaan di Kabupaten Mojokerto selama 20152017 silam terhitung relatif tinggi.

Berdasarkan data Tabel 1, dapat dilihat bahwa jumlah kecelakaan lalu lintas berdasarkan usia yang paling dominan pada kisaran usia 19-27 tahun, sebanyak 1.532 orang, kemudian selanjutnya paling banyak adalah pada kisaran usia 9-12 tahun yaitu 637 orang dan kemudian yang paling banyak ketiga adalah pada kisaran 13-18 sebanyak 616 orang. Jika pada kisaran usia tersebut maka dapat dipastikan 
bahwa kecelakaan lalu lintas di Kabupaten Mojokerto disebabkan oleh kelompok usia anak dan remaja. Hal ini tentu sudah harus menjadi perhatian serius.

Tabel 1.

Jumlah Kecelakaan Lalu Lintas di Wilayah Hukum Polres Mojokerto Berdasarkan Usia

\begin{tabular}{lcccc}
\hline \multicolumn{1}{c}{ Usia } & \multicolumn{3}{c}{ Tahun } & Jumlah \\
\cline { 2 - 4 } & 2015 & 2016 & 2017 & \\
\hline $9-12$ tahun & 197 & 220 & 220 & 637 \\
\hline $\begin{array}{l}13-18 \\
\text { tahun }\end{array}$ & 200 & 228 & 188 & 616 \\
$\begin{array}{l}19-27 \\
\text { tahun }\end{array}$ & 410 & 510 & 612 & 1531 \\
\hline $\begin{array}{l}28-35 \\
\text { tahun }\end{array}$ & 100 & 99 & 157 & 357 \\
\hline $\begin{array}{l}35-45 \\
\text { tahun }\end{array}$ & 134 & 188 & 192 & 514 \\
\hline $\begin{array}{l}46-55 \\
\text { tahun }\end{array}$ & 145 & 133 & 157 & 435 \\
\hline $\begin{array}{l}\text { Jumlah } \\
\text { Jumlann}\end{array}$ & 1.186 & 1.378 & 1.526 & 4090 \\
\hline
\end{tabular}

Sumber: Data laka lantas Polres Mojokerto, 2017

Sejak diberlakukannya Undang-Undang Sistem Peradilan Anak penyelesaian hukum terhadap anak yang berhadapan dengan hukum, maka peradilan semakin mengedepankan nilai-nilai keadilan, kesejahteraan, dan menjunjung tinggi perlindungan hak asasi manusia terhadap anak. Nuansa keadilan diversi sebagaimana yang diamanatkan dalam undang-undang tersebut menjadi muatan yang benarbenar membawa angin segar dalam konteks penyelesaian tindak pidana. Sehingga penyelesaian tidak lagi bertujuan untuk pembalasan semata tetapi ditekankan kepada pemulihan kembali dalam keadaan semula.

Penyelesaian secara adil yang dikemas dalam bentuk keadilan diversi tersebut kemudian diwujudkan dalam bentuk pengalihan penyelesaian perkara yang keluar jalur sistem peradilan pidana yang kemudian dikenal dengan istilah diversi. Diversi merupakan ide dasar untuk menghilangkan dampak negatif dari sistem peradilan pidana yang selalu menghasilkan stigma negatif yang kemudian melabel anak-anak sesuai dengan perbuatan yang terjadi kepadanya (Wahid 2009; Hambali 2019). Ide dasar diversi mulai di gagas dalam United Nations Standard Minimum Rules for the Administration of Juvenile Juatice (SMRJJ) atau yang dikenal dengan The Beijing Rules.

Diversi merupakan pemberian kewenangan kepada aparat penegak hukum untuk mengambil tindakantindakan kebijaksanaan dalam menangani atau menyelesaikan masalah pelanggar anak dengan tidak mengambil jalan formal antara lain menghentikan atau tidak meneruskan/melepaskan dari proses peradilan pidana atau memgembalikan atau menyerahkan kepada masyarakat dalam bentuk-bentuk kegiatan pelayanan sosial lainnya (Sosiawan 2016; Ratomi 2013). Kasus kecelakan lalu lintas dengan pelaku anak di bawah umur seringkali menimbulkan kontroversi dalam penerapan hukum pidana sehingga banyak menimbulkan polemik (Astuti 2017).

Pendapat bahwa proses hukum harus tetap dilaksanakan dan harus ditegakkan tanpa pandang bulu (rule of law dan law enforcement), karena "kelalaiannya" yang termasuk delik culpa/kealpaan yaitu pada saat mengemudikan kendaraan hingga menyebabkan terjadinya kecelakaan tetap harus diproses secara hukum. Diversi menjadi jawaban atas tujuan dari penyelesaian perkara anak secara adil. Hanya saja dalam menerapkan diversi diperlukan beberapa persyaratan tertentu.

Diversi baru dapat dilakukan dengan melihat usia anak, sifat perbuatan tersebut apakah baru pertama kali dilakukan atau merupakan bentuk pengulangan, diberlakukan dalam tindak pidana ringan, adanya persetujuan dari korban dan kesepakatan para pihak, serta kerelaan masyarakat untuk mendukung proses diversi. 
Sementara itu, terdapat peraturan resmi mengenai lalu lintas dan angkutan jalan. Pasal 1 butir 1 Undang-Undang Nomor 22 Tahun 2009 menjelaskan tentang lalu lintas dan angkutan jalan adalah satu kesatuan sistem yang terdiri atas lalu lintas, angkutan jalan, jaringan lalu lintas dan angkutan jalan, prasarana lalu lintas dan angkutan jalan, kendaraan, pengemudi, pengguna jalan, serta pengelolaannya. Sedangkan pada Pasal 1 butir 2, lalu lintas didefinisikan sebagai gerak kendaraan dan orang di ruang lalu lintas jalan. Sementara yang dimaksud dengan ruang lalu lintas jalan adalah prasarana yang diperuntukkan bagi gerak pindah kendaraan, orang, dan/atau barang yang berupa jalan dan fasilitas pendukung.

Sementara itu, penyelenggara lalu lintas dan angkutan jalan, diatur dalam Pasal 3 UU No 22 tahun 2009 tentang lalu lintas dan angkutan jalan yang menerangkan bahwa lalu lintas dan angkutan jalan diselenggarakan dengan tujuan terwujudnya pelayanan lalu lintas dan angkutan jalan yang aman, selamat, tertib, lancar, dan terpadu dengan moda angkutan lain untuk mendorong perekonomian nasional, memajukan kesejahteraan umum, memperkukuh persatuan dan kesatuan bangsa, serta mampu menjunjung tinggi martabat bangsa, terwujudnya etika berlalu lintas dan budaya bangsa, dan terwujudnya penegakan hukum dan kepastian hukum bagi masyarakat.

Pasal 1 butir 24 Undang-Undang Republik Indonesia Nomor 22 tahun 2009 tentang lalu-lintas dan angkutan jalan menjelaskan bahwa yang dimaksud kecelakaan lalu lintas adalah suatu peristiwa di jalan yang tidak diduga dan tidak disengaja melibatkan. Kendaraan dengan atau tanpa pengguna jalan lain yang mengakibatkankorban manusia dan/atau kerugian harta benda. Menurut Djajoesman kecelakaan lalu lintas diartikan sebagai suatu kejadian yang tidak disengaja atau tidak disangka-sangka dengan akibat kematian, luka atau kerugian benda. Kecelakaan selalu mengandung unsur tidak sengaja atau yang tidak disangka sangka menimbulkan rasa heran atau tercengang kepada orang yang mengalami itu (Sakti 2012).

Undang-undang Nomor 22 Tahun 2009 tentang lalu lintas dan angkutan jalan Pasal 1 Poin 24 menjelaskan definisi kecelakaan lalu lintas sebagai suatu peristiwa di jalan yang tidak diduga dan tidak disengaja melibatkan kendaraan dengan atau tanpa pengguna jalan lain yang mengakibatkan korban manusia dan/atau kerugian harta benda. Pasal 229 mengatur tentang penggolongan kecelakaan lalu lintas, yaitu kecelakaan lalu lintas ringan merupakan kecelakaan yang mengakibatkan kerusakan kendaraan dan/atau barang, kecelakaan lalu lintas sedang merupakan kecelakaan yang mengakibatkan luka ringan dan kerusakan kendaraan dan/atau barang, kecelakaan lalu lintas berat merupakan kecelakaan yang mengakibatkan korban meninggal dunia atau luka berat. Secara prinsip setiap kecelakaan lalu lintas jalan yang menimbulkan korban jiwa manusia harus dilakukan investigasi dan penelitian untuk mengetahui kemungkinan penyebab kecelakaan yang dapat dijadikan rekomendasi guna mencegah terjadinya kecelakaan serupa terulang kembali (Al Qurni 2013; Putri 2014; Marsaid et al 2012; Azizirrahman et al 2015).

Saat ini, kriteria kecelakaan yang diinvestigasi dan diteliti adalah kecelakaan lalu lintas jalan yang bersifat luar biasa yaitu kecelakaan lalu lintas jalan yang menimbulkan korban manusia yang mati delapan orang atau lebih, lecelakaan lalu lintas jalan yang menyebabkan prasarana rusak berat, kecelakaan lalu lintas jalan yang mengundang perhatian publik secara luas, karena melibatkan tokoh ternama/penting atau figur publik, kecelakaan lalu lintas jalan yang menimbulkan polemik/ kontroversi, kecelakaan yang berulang-ulang pada merk dan tipe kendaraan yang sama, kecelakaan yang sama pada satu titik lokasi lebih dari tiga kali dalam setahun, kecelakaan lalu lintas jalan yang mengakibatkan kerusakan/pencemaran lingkungan akibat bahan/limbah berbahaya beracun (B3).

Apabila terjadi kecelakaan seperti kriteria di atas, Unit Peneliti Kecelakaan Lalu Lintas (UPK) tingkat provinsi harus melakukan investigasi terhadap lokasi kejadian.dengan tujuan untuk mendapatkan penyebab terjadinya kecelakaan ini. Jika kecelakaan yang terjadi melibatkan dan mengakibatkan sebagai kecelakaan yang berskala tingkat nasional, maka UPK pusat bekerja sama dengan UPK provinsi yang harus melakukan investigasinya. 
Konsep anak menurut Undang-Undang Republik Indonesia Nomor 23 Tahun 2002 tentang Perlindungan Anak adalah seseorang yang belum berusia 18 (delapan belas) tahun, termasuk anak yang masih dalam kandungan. Anak adalah bukan orang dewasa dalam bentuk kecil, melainkan manusia yang oleh karena kondisinya belum mencapai taraf pertumbuhan dan perkembangan yang matang, maka segala sesuatunya berbeda dengan orang dewasa pada umumnya.

Sementara itu, pengertian anak menurut UU RI Nomor 4 Tahun 1979, tentang kesejahteraan anak, anak adalah seseorang yang belum mencapai usia 21 tahun dan belum pernah menikah. Batas 21 tahun ditetapkan karena berdasarkan pertimbangan usaha kesejahteraan sosial, kematangan pribadi, dan kematangan mental seorang anak dicapai pada usia tersebut. Anak adalah potensi serta penerus bangsa yang dasar-dasarnya telah diletakkan oleh generasi sebelumnya. Dalam regulasi, setiap anak berhak untuk memperoleh perlindungan dari penyalahgunaan dalam kegiatan politik, pelibatan dalam sengketa bersenjata, pelibatan dalam kerusuhan social, pelibatan dalam peristiwa yang mengandung unsur kekerasan yaitu pelibatan dalam peperangan dan kejahatan seksual.

Proses pelaksanaan diversi dalam sistem peradilan pidana di Indonesia memegang prinsip memperhatikan kepentingan korban, kesejahteraan dan tanggung jawab anak, penghindaran stigma negatif, penghindaran pembalasan, keharmonisan masyarakat, dan kepatutan, kesusilaan, dan keharmonisan (Mimi et al 2014). Diversi mempunyai suatu kerangka pikir dalam upaya mencari alternatif penyelesaian terhadap kasus tindak pidana yang dilakukan oleh anak tanpa hukuman pidana (Astuti 2017; Hartono 2015).

Dalam sistem peradilan pidana anak di Indonesia para penegak hukum diwajibkan untuk mengupayakan diversi pada setiap tahapan baik penyidikan, penuntutan serta pemeriksaan di pengadilan. Di samping itu diversi adalah pengalihan penyelesaian perkara anak dari proses peradilan pidana ke proses diluar peradilan pidana. Diversi bertujuan mencapai perdamaian antara korban dan anak, menyelesaikan perkara anak diluar proses peradilan, menghindarkan anak dari perampasan kemerdekaan, mendorong masyarakat untuk berpartisipasi, dan menanamkan rasa tanggung jawab kepada anak (Munajah 2015).

\section{Metode Penelitian}

Penelitian ini menggunakan pendekatan kualitatif (Moleong 2007). Penelitian ini mengambil lokasi di wilayah hukum Polisi Resort (Polres) Mojokerto, melihat tingginya angka kecelakaan yang melibatkan anak di bawah umur. Penelitian ini menggunakan teknik pengumpulan data dengan wawancara mendalam, observasi dan dokumentasi. Informan penelitian ini adalah Kanit Laka Lantas, Penyidik, Anggota Satlantas Polres Mojokerto, keluarga korban, pelaku anak dan orang tua pelaku anak. Data dianalisis dengan menggunakan teori dan studi-studi terdahulu yang relevan dengan topik yang dikaji dalam studi ini.

\section{Hasil dan Pembahasan}

\section{Karakteristik kecelakaan lalu lintas anak di wilayah hukum Polres Mojokerto}

Karakteristik kecelakaan lalu lintas di wilayah hukum Polres Mojokerto paling dominan disebabkan oleh anak dan remaja pada kisaran usia usia 9-12 tahun yaitu 637 orang dan yang paling banyak ketiga adalah pada kisaran 13-18 sebanyak 616 orang, di mana kisaran usia tersebut adalah anak sekolah. Selanjutnya, jika dilihat dari tingkat pendidikan, maka paling banyak disebabkan oleh siswa SLTA berjumlah 1.532 anak, SLTP berjumlah 435, serta SD sebanyak 285 anak.

Kecelakaan lalu lintas yang melibatkan anak di Polres Mojokerto yaitu pelaku anak sesungguhnya dapat dipidanakan, namun karena sistem peradilan anak di Indonesia masih memperhatikan mental anak dalam perkara sidang, maka diajukan cara atau pendekatan diversi dalam proses penyidikan dan penyelidikan sehingga mencapai suatu kesepakatan penyelesaian antara pelaku dan korban atau keluarga korban. Hal ini dibuktikan bahwa proses penghukuman yang diberikan kepada anak lewat 
sistem peradilan pidana formal dengan memasukkan ke penajara tidak berhasil menjadikan anak jera dan lebih menghambat proses tumbuh-kembang anak.

Strategi penyelesaian kecelakaan lalu lintas pelaku anak dengan pendekatan diversi di wilayah hukum Polres Mojokerto

\section{Mengadakan sosialisasi tentang diversi di kalangan masyarakat}

Polres Mojokerto bekerja sama dengan instansi yang terkait, seperti Pengadilan Tinggi wilayah Mojokerto, BPMPKB (Badan Pemberdayaan Masyarakat dan Perempuan dan Keluarga Berencana) Kabupaten Mojokerto, aparat penegak hukum yang lain dan pihak lainnya untuk mengadakan pertemuan dengan masyarakat di Kabupaten Mojokerto untuk memperkenalkan Undang-Undang Sistem Peradilan Pidana Anak terutama tentang diversi dan peranan dari pihak-pihak yang terlibat, seperti para penegak hukum (penyidik, penuntut umum dan hakim) serta pembimbing kemasyarakatan dan pekerja sosial profesional/tenaga kesejahteraan sosial agar masyarakat lebih memahami diversi dan dapat memperbaiki pelabelan yang buruk terhadap para penegak hukum. Kemudian, untuk memberikan pemahaman kepada orang tua/wali dari anak biasanya penuntut umum melakukan pemanggilan dan pemberitahuan kepada orang tua/wali dengan mengirimkan surat panggilan kepada orang tua/wali anak.

\section{Mediasi antara pihak korban dan pihak anak yang berkonflik}

Upaya diversi tidak selalu mencapai kesepakatan, namun hal yang akan dipertimbangkan dalam kesepakatan tersebut adalah pasal pelanggaran yang dilakukan anak serta usia anak (Nurwaianti et al. 2017, Hartono 2015). Pemikiran antara pihak korban dan pihak anak yang berkonflik yang berpotensi tidak mencapai kesepakatan, Polres Mojokerto dalam pendampingan diversi perlu melakukan upayaupaya semaksimal mungkin agar kedua belah pihak yang berkonflik dapat mencapai kesepakatan diversi, yang mana hasilnya akan menghindari pidana anak. Sesuai dengan yurisdiksi penanganan anak yang berhadapan dengan hukum, maka batasan umur anak yang dipakai adalah sesuai UndangUndang No. 11 tahun 2012 tentang Sistem Peradilan Pidana Anak, yaitu anak adalah yang telah mencapai umur 12 tahun sampai 18 Tahun dan belum pernah kawin.

Sementara itu, hal-hal yang perlu menjadi pertimbangan dalam pelaksanaan diversi apabila ingin mencapai kesepakatan, yaitu; pertama, sifat dan kondisi perbuatan. Pertimbangan pertama diversi adalah tingkat keseriusan dalam perbuatan. Apakah ringan, sedang, atau berat. Latar belakang dari perbuatan dapat menjadi pertimbangan dilakukannya pelanggaran yang sebelumnya pernah dilakukan. Jika sebelumnya anak pernah melakukan pelanggaran hukum ringan, diversi dan diskresi harus tetap menjadi pertimbangan. Jika anak sering melakukan pelanggaran hukum, maka sulit dilakukan diversi, namun demikian perlu dilakukan langkah hati-hati dan pemikiran matang dan demi kepentingan terbaik bagi anak, dan perlu dirujuk pada jasa pelayanan profesional yang kompeten. Kedua, derajat keterlibatan anak dalam kasus. Sementara pihak lain yang terlibat dalam suatu perbuatan pelanggaran. Ketiga, telah merencanakannya dan mengambil bagian yang aktif, seorang anak biasanya baru terlibat di saat-saat terakhir dan hanya berperan sebagai pengintai/penjaga. Derajat keterlibatan seorang anak akan sangat berperan dalam mempertimbangkan diversi dan diskresi baginya. Keempat, sikap anak terhadap perbuatan tersebut. anak mengakui perbuatannya dan menyesalinya, hal ini menjadi pertimbangan yang positif untuk diversi.

Kelima, reaksi orangtua dan/atau keluarga anak terhadap perbuatan tersebut. Dukungan dari orangtua dan keluarga sangat penting agar diversi dapat berhasil. Jika pihak keluarga menutupnutupi perbuatan anak, maka rencana diversi yang efektif akan sulit untuk diimplementasikan. Keenam, usul yang diberikan untuk melakukan perbaikan atau meminta maaf pada korban. Permintaan maaf kepada korban adalah indikasi yang jelas bagi korban bahwa anak mau bertanggungjawab atas perbuatannya. Jika anak belum siap untuk meminta maaf atas perbuatannya, maka diversi sulit dilakukan. Ketujuh, dampak perbuatan terhadap korban. Jika kejahatan berdampak sangat serius pada korban, meskipun anak tidak bermaksud demikian, maka diversi mungkin tidak menjadi pilihanPandangan korban tentang metode penanganan yang ditawarkan. Agar diversi dapat direncanakan dengan baik, maka 
harus ada masukan dan/atau persetujuan dengan pihak korban. Kedelapan, dampak sanksi atau hukuman yang sebelumnya pernah diterima terhadap anak. Jika anak pernah berhadapan dengan hukum sebelumnya, dan sanksi dahulu tidak direspon dengan positif oleh si anak, maka diversi tidak dapat menjadi pilihan, kecuali pelanggaran dahulu tergolong ringan atau telah lama sekali terjadi. Apabila demi kepentingan publik, maka proses hukum harus dilaksanakan.

\section{Membangun komunikasi interaktif antar instansi}

Komunikasi merupakan faktor yang berperan penting sebagai acuan bagi implementator (pelaksana) kebijakan guna mengetahui apa yang harus dikerjakan, di samping itu juga sebagai perintah dari atasan terhadap implementator kebijakan sehingga komunikasi tersebut harus dinyatakan jelas, tepat dan konsisten dalam penerapan kebijakan agar tidak keluar dari sasaran yang hendak dicapai. (Nugroho 2008). Keberhasilan komunikasi sebagai faktor penentu implementasi kebijakan ditentukan oleh bagaimana implementator memahami kejelasan isi pesan yang disampaikan untuk diteruskan pada pelaksana, selain itu juga kebijakan tersebut mendapat pengaruh yang signifikan oleh kompleksitas isi kebijakan, konteks kebijakan, karakter lingkungan tempat kebijakan dilaksanakan dan karakter pelaksana. (Nugroho 2008).

Upaya yang dilakukan penuntut umum dalam hambatan mengenai perbedaan pemahaman dengan penyidik dan hakim pada penanganan perkara anak yang berkonflik dengan hukum yaitu melakukan komunikasi dengan penyidik dan pihak kejaksaan apabila telah dilakukan proses penyidikan agar terwujudnya keadaan yang saling memahami perbedaan keyakinan penafsiran pasal satu sama lain.

Perbedaan pemahaman mengenai pedoman pelaksanaan diversi mempengaruhi komunikasi antar Polres Mojokerto dengan penegak hukum lainnya, seperti kejaksanaan. Oleh karena itu, dibutuhkan kerja sama serta komunikasi baik formal maupun informal mengenai pelaksanaan diversi pada anak pelaku kecelakaan lallu lintas di wilayah hukum Polres Mojokerto. Di Indonesia pengaturan diversi terdapat dalam ketentuan UU No.11 Tahun 2012 tentang Sistem Peradilan Pidana Anak, yaitu pengalihan penyelesaian perkara anak dari proses peradilan pidana anak ke proses di luar sistem peradilan pidana anak (Pasal 1 angka 7 UU SPPA) Kewajiban melaksanakan diversi diatur dalam Pasal 6 sampai dengan Pasal 15 UU SPPA.

Diversi berupaya memberikan keadilan kepada kasus-kasus anak yang telah terlanjur melakukan tindak pidana sampai kepada aparat penegak hukum sebagai pihak penegak hukum. Tujuan dari diversi yaitu untuk menghindari penahanan, menghindari cap/label sebagai penjahat, meningkatkan keterampilan hidup bagi pelaku agar pelaku bertanggung jawab atas perbuatannya, mencegah pengulangan tindak pidana, memajukan intervensi-intervensi yang diperlukan bagi korban dan pelaku tanpa harus melalui proses formal, program diversi juga akan menghindari anak mengikuti proses sistem peradilan, program diversi ini akan menjauhkan anak-anak dari pengaruh-pengaruh dan implikasi negatif dari proses peradilan tersebut.

\section{Kendala dalam melaksanakan penyelesaian kecelakaan lalu lintas oleh anak dengan pendekatan diversi}

\section{Kurangnya pemahaman masyarakat mengenai diversi}

Masyarakat Kabupaten Mojokerto merupakan masyarakatnya yang masih menganggap bahwa apabila terdapat suatu tindak pidana yang dilakukan oleh seseorang maka harus di proses melalui jalur hukum (pengadilan). Begitu pula dengan tindak pidana yang dilakukan oleh anak-anak. Selain itu, keluarga korban dan keluarga anak sebagai bagian dari masyarakat juga belum memahami mengenai diversi ini.

\section{Tidak tercapainya kesepakatan diversi}

Ketika menentukan kesepakatan antara pihak korban dan pihak anak tidak mudah. Pada saat musyawarah diversi dilakukan ketika pihak anak yang berkonflik dengan hukum dan pihak korban 
bertemu di ruang diversi sering terjadi pertengkaran atau keributan yang mengakibatkan musyawarah diversi menjadi tidak kondusif. Sehingga terkadang keluarga korban tidak ingin sepakat dengan cara diversi atau mengindari pidana, karena alasan keadilan. Hal ini dapat diartikan bahwa perbedaan kepentingan antara keduanya merupakan masalah mendasar dalam penentuan kesepakatan. Terkadang permintaan pihak korban tidak dapat dipenuhi oleh pihak anak yang berkonflik dengan hukum karena syarat-syarat yang diajukan oleh pihak korban dianggap terlalu berlebihan namun pihak korban pun tidak ingin mengubah persyaratan kesepakatannya sehingga pelaksanaan diversi gagal dilakukan.

\section{Pemahaman yang berbeda dalam penanganan anak yang berkonflik dengan hukum diantara aparat penegak hukum}

Pemahaman yang berbeda-beda mengenai penanganan anak yang berkonflik dengan hukum maksudnya adalah diantara para penegak hukum dalam menafsirkan mengenai isi beberapa pasal dalam peraturan perundang-undangan berbeda sehingga menimbulkan perbedaan pendapat dalam penanganannya. Jika sering terjadi multitafsir mengenai pasal-pasal tertentu dalam pedoman pelaksanaan diversi, misalnya penafsiran yang berbeda mengenai syarat dilakukannya diversi yang terdapat dalam Pasal 7 ayat (2) Undang-Undang Nomor 11 Tahun 2012 tentang Sistem Peradilan Pidana Anak, yang menyatakan bahwa "diversi dilaksanakan dalam hal tindak pidana yang dilakukan dengan ancaman pidana penjara di bawah 7 (tujuh) tahun dan bukan merupakan pengulangan tindak pidana.

\section{Simpulan}

Kasus kecelakaan lalu lintas di wilayah hukum Polres Mojokerto didominasi oleh kecelakaan yang disebabkan anak-anak dan remaja. Kasus seperti ini agak sulit ditangani sebab terhalang oleh undangundang perlindungan anak dan kewajiban memperhatikan mental dan kondisi anak. Oleh sebab itu, Polres Mojokerto melakukan pendekatan diversi untuk menyelesaikan kasus melalui penyidikan dan mendorong kesepakatan keluarga pelaku dan korban. Hal ini dilakukan atas asas hak anak-anak yang memperhatikan tumbuh kembang anak. Di samping itu strategi penyelesaian kecelakaan lalu lintas pelaku anak dengan pendekatan diversi di Wilayah Hukum Polres Mojokerto adalah dengan mengadakan sosialisasi tentang diversi di kalangan masyarakat, upaya menyatukan pemikiran antara pihak korban dan pihak anak yang berkonflik dengan hukum agar tercapainya kesepakatan dan menjalin komunikasi yang intensif dengan aparat penegak hukum yang lainnya.

Kendala dalam melaksanakan penyelesaian pada kecelakaan lalu lintas pelaku anak di Wilayah Hukum Polres Mojokerto adalah pemahaman masyarakat mengenai diversi, pemikiran antara pihak korban dan pihak yang berkonflik dengan hukum agar tercapainya kesepakatan dan pemahaman yang berbeda dalam penanganan anak yang berkonflik dengan hukum di antara aparat penegak hukum.

\section{Daftar Pustaka}

Al Qurni I (2013) Analisis Rawan Kecelakaan Lalu Lintas di Jalan Nasional Kabupaten Kendal. Skripsi: Universitas Negeri Semarang.

Astuti L (2017) Perlindungan hukum terhadap anak yang berhadapan dengan hukum dalam kecelakaan lalu lintas. Justitia Jurnal Hukum 1 (1):144-157.

Azizirrahman M, Normelani E \& Arisanty D (2015) Faktor penyebab terjadinya kecelakaan lalu lintas pada daerah rawan kecelakaan di Kecamatan Banjarmsasi Tengah Kota Banjarmasin. Jurnal Pendidikan Geografi 2 (3):20-37.

Hambali AR (2019) Penerapan diversi terhadap anak yang berhadapan dengan hukum dalam sistem peradilan pidana. Jurnal Ilmiah Kebijakan Hukum 13 (1):16 - 29.

Hartono B (2015) Penyelesaian perkara melalui diversi sebagai upaya perlindungan anak pelaku tindak pidana. Pranata Hukum 10 (1):75-85. 
Marsaid, Hidayat M, Ahsan (2013) Faktor yang berhubungan dengan kejadian kecelakaan lalu lintas pada pengendara sepeda motor di wilayah Polres Kabupaten Malang. Jurnal Ilmu Keperawatan $1(2): 98-112$.

Mimi U, Pello J \& Medan K (2014) Diversi dalam perlindungan hukum anak yang bermasalah hukum dalam sistem peradilan pidana anak. MMH Jilid 43 (2):305-312.

Moleong LJ (2007) Metodologi Penelitian Kualitatif. Bandung: Remaja Rosdakarya.

Munajah (2015) Upaya diversi dalam proses peradlan pidana anak Indoonesia. Al'Adl 7 (14):28-34.

Nugroho R (2008) Public Policy: Teori Kebijakan-Analisis Kebijakan-ProsesKebijakan, Perumusan, Implementasi, Evaluasi, Revisi, Risk Manajementdalam Kebijakan Publik, Kebijakan sebagai The Fith Estate, MetodeKebijakan. Jakarta: PT Elex Media Komputindo.

Nurwaianti A, Gunarto, \& Wahyuningsih SE (2017) Implementasi restoratif/ restorative justice dalam penyelesaian tindak pidana kecelakaan lalu lintas yang dilakukan oleh anak di Polres Rembang. Jurnal Hukum Khaira ummah 12 (4):705-716.

Putri CE (2014) analisis karakteristik kecelakaan dan faktor penyebab kecelkaan pada loksi blackspot di Kota Kayu Agung. Jurnal Teknik Sipil Dan Lingkungan 2 (1):154 - 161.

Ratomi A (2013) Konsep prosedur pelaksanaan diversi pada tahap penyidikan dalam penyelesaian tindak pidana yang dilakukan oleh anak. Arena Hukum 6 (3):394 - 407.

Sakti BPK (2012) Analisis penentuan lokasi rawan kecelakaan lalu lintas di jalur utama kabupaten jember (metode pencacahan indikator kerawanan). Jurnal Teknik Sipil Universitas Jember 6 (1):12-24.

Sosiawan UM (2016) Perspektif restorative justice sebagai wujud perlindungan anak yang berhadapan dengan hukum. Jurnal Penelitian Hukum 16 (4):425 - 438.

Undang-Undang Republik Indonesia Nomor 23 Tahun 2002 Tentang Perlindungan Anak.

Undang-Undang Republik Indonesia Nomor 22 Tahun 2009 Tentang Lalu Lintas dan Angkutan Jalan.

Wahid E (2009) Keadilan Restoratif dan Peradilan Konvensional dalam Hukum Pidana. Jakarta: Universitas Trisakti. 